\title{
IMMIGRATION AND OUR FOREIGN POLICY OBJECTIVES
}

\author{
J. Donald Kingsley*
}

I

It has been said of the United States that we are the only nation to have reached the status of a great power without having fashioned a foreign policy. This is, undoubtedly, an exaggeration. We have forged, in the past, as much of a foreign policy as we have required. The truth is that foreign policy is only an adjunct to foreign relations, and in our case, both were circumscribed and episodic before I9I4. Eastward, the European balance of power, skillfully and brilliantly maintained by England, was favorable to our growth and security. British control of the Atlantic, counterbalanced as it was by our own strategic preponderance in respect to Canada, presented no challenge to us. We required no policy toward Europe because the British Foreign Office had a policy which it effectively implemented.

In a limited way, to be sure, we played a role in maintaining the European power balance through the Monroe Doctrine, first suggested to us by the British. But this, too, was effective, in large measure, because it was backed by English sea power, and we scarcely saw it as related to the balance of power in Europe in any way.

Under these idyllic and historically unique circumstances, we were left free for more than a century to concentrate on our own internal problems: to populate our continental land mass, to press westward to the Pacific, to develop our domestic economy, and to stabilize our domestic political institutions. If we thought of the Old World at all, it was principally as a labor market, except among those of us who had just arrived ourselves. Then, we sometimes had other thoughts and other yearnings, as several score immigrant writers have indicated. But our nostalgia was tempered by the sweeping opportunities of a continental expansion and by the daily translation of the American dream. We did not entirely forget, and, from time to time, our remembrance was reflected in domestic politics and even in our foreign relations. But mostly we looked ahead rather than back. Millions came. Few returned.

The image of America in the minds of Europeans during this period was similarly circumscribed and positive. To a remarkable degree, it was not only symbolized by, but encompassed by, the Statue of Liberty, holding the torch of freedom on Bedloe's Island. In this statue was embodied one of the greatest mother images

*A.B. 1929, M.A. I930, Ph.D. I933, Syracuse University; LL.D. I950, University of Louisville. Exccutive Director, Welfare and Health Council of New York, since 1953. Formerly Administrator, Paris Refugee Reparations Fund; Director General, International Refugee Organization; United Nations Agent General, Korean Reconstruction; Member, United States Delegation to United Nations Economic and Social Council. Co-author [with William E. Mosher], Public Personnel Administration (2d ed. 1940); author, Representative BuREAuCRACY (1944). 
of all time, offering comfort, security, and peace to the oppressed, the disinherited, the dissatisfied. Looking toward Europe, its light showed across the Atlantic and burned deeply into the consciousness of all the peoples of Europe. The image was still bright, even after World War II, when four out of five of the million displaced persons who were resettled overseas by the International Refugee Organization wished, as their first choice, to come to the United States. To many, it was a shock to discover that they could not do so.

European statesmen and rulers did not, of course, think of America as the less privileged did. In the golden period before the lights went out, statesmen were not seeking a haven outside Europe. And since we had limited relations with them, they seldom thought of us at all. This is clear from even a cursory perusal of the voluminous memoirs left by Victorian diplomats and statesmen. When they did think of us, it was with a certain condescension as an underdeveloped area, or as a commercial market. Harold Nicolson has described the corporate unity of the European diplomatic corps in the days of the "old diplomacy": the similarity of breeding, education, background, and aspirations among its members. ${ }^{1}$ Our representatives were not included in this exclusive club, which, for a century, managed the power balance in Europe and helped to preserve the peace.

But while we played little role in the affairs of Europe before World War I, the circumstances of our history, and particularly of our immigration history, forged a series of significant bonds between us and the peoples of Europe: familial, cultural, ideological. For five generations of Europeans, the inscription on the base of the Statue of Liberty represented American policy, while the revolutionary dream of equal opportunity was closely enough approximated in the experience of the European immigrant to maintain its magnetism and its political magic. Thus was built, through the years, a moral strength in the eyes of Europe which has contributed mightily to our emergence as leader of the western coalition. When we finally intervened directly in World War I to maintain the balance of power in Europe and to prevent Germany from wresting control of the Atlantic from Britain, the European world was prepared for the moral leadership of Wilson. However unrealistic the Wilsonian program, it reinforced the European image of America and American ideals. Nor was that image substantially blurred by the restrictive immigration legislation of the I920's, as it applied to Europe.

American attitudes towards immigration had, in fact, been undergoing a subtle change ever since 1880 . By that time, we had come to the end of the period of unrestricted labor demand, and the organization of labor had reached a point where protests against the competition of foreign workers were mounting. After 1882 , the federal government began to impose qualitative restrictions on European immigration, though no attempt was made until I9I7 to reduce the numbers of immigrants. The I9I7 law marked finis to our traditional immigration policy, for its literacy re-

${ }^{1}$ Harold Nicolson, The Evolution of Diplomatic Method 72 el seq. (1954). 
quirements were explicitly designed to limit the numbers of immigrants. ${ }^{2}$ It is significant that it was passed-as so much of our restrictive immigration legislation has been passed-over the veto of the President. The executive branch, charged with responsibility for the conduct of our foreign relations, has been traditionally hesitant in approval of restrictive and discriminatory measures.

While congressional intent to limit immigration is clear in the legislative history of the $\mathrm{rgI}_{7}$ law, the means employed were relatively ineffective. Immigration understandably came to a halt with our entrance into World War I. But in x92x, we experienced a net immigration of more than 500,000. This, combined with a postwar fear of aliens and of "radical" ideas led not only to mass harassment and deportations, but to the emergency quota law of $\mathrm{rg2r}$, which inaugurated the present policy of severe restriction." The "temporary" approach of I92I was made permanent in 1924, when we solemnly reversed our historic immigration policy vis a vis Europe and adopted, instead, a discriminatory program of restriction based primarily on national origins and rooted in dubious biological and anthropological assumptions."

That this historic departure did not more seriously affect our relations with Europe or the European view of America was attributable to a number of factors. Foremost among them was the imminent onslaught of the Great Depression. In the absence of economic opportunity, the stream of immigration was first reduced to a trickle and then, for a time, reversed. The economic crisis was followed by the second German attempt in a generation to shatter the European power balance and by World War II. In the years immediately following the war, the impact on Europe of our permanent immigration policy was cushioned by the provisions of the Displaced Persons Act of 1948 , as amended in $1950,{ }^{5}$ under which nearly 400,000 refugees and displaced persons were admitted, against the future "mortgaging" of quotas. More recently, still, the "Escapee Program," with its special provisions for Italian and Greek immigration, has again provided an emergency escape hatch in the barriers raised toward Europe. ${ }^{6}$

II

But Europe, as we are currently rediscovering, is not the world. Indeed, it has been historically of far less interest to American statesmen and policy-makers than has Asia. And in Asia, the popular image of America and the impact of our immigration policies on that image have been far different. From earliest times, we as a people have looked toward the setting sun. When "manifest destiny" had run its

\footnotetext{
'The principal congressional enactments during this period were: Act of Aug. 3, 1882, c. 376,22 Stat. 214; Act of March 3, 1891, c. 551, 26 Stat. ro84; Act of March 3, 1893, c. 206, 27 Stat. 569; Act of March 3, I903, c. I012, 32 STAT. I214; Act of Feb. 20, I907, c. II34, 34 STAT. 898; Act of June 25, r910, c. 395, 36 Star. 825; Act of March, 26, r91o, c. 128, 36 STAT. 263; Act of Feb. 5, I917, c. 29,39 STAт. 874 .

${ }^{3}$ Act of May 19, I921, c. 8, 42 Stat. 5, amended, id. 540 (1922). See Emith Abbott, Immigration: Select Documents and Case Records 242 (1924).

- Act of May 26, 1924, c. I90, 43 STAT. I53.

'62 Srat. 1009 (1948), as amended, 50 App. U. S. C. \$\$ 1951-63 (I952).

- Refugee Relief Act of I953, 67 STAT. 400, as amended, 50 App. U. S. C. A. § I971 (1955 Supp.).
} 
continental course in the conquest of Texas and of California, we did not stop at the water's edge.

It is, of course, doubtful that we could have stopped there had we wished. In the Pacific, we found no such secure bulwark as was represented by the English fleet in the Atlantic. While the European power balance extended through the colonial system to much of Asia-and even to Africa-its effective maintenance in the Far East could be assured only by a Pacific power. We quickly set about to become such a power and-for a time-dreamed of oriental empire. ${ }^{7}$

This is, of course, no place in which to review history in detail. But our interest in the Far East dated back to the early China trade and became major with the acquisition of California. In 1853 , Commodore Perry showed the flag in Tokyo Bay and opened Japan to western ideas and trade, thus sparking a chain of events which ultimately led to Pearl Harbor. "It is self-evident," he wrote at the time, "that the course of coming events will ere long make it necessary for the United States to extend its jurisdiction beyond the limits of the western continent, and I assume the responsibility of urging the expediency of establishing a foothold in this quarter of the globe. ..."8

Not long after, another naval officer, Captain A. T. Mahan, established himself as the outstanding theoretician of American foreign policy of his day. "Whether they will or no," he wrote in his famous exposition of the relation of sea power to world status, "America must now begin to look outward." His vision, too, was focused upon the Pacific.

Quickly, then, we built up our naval strength, acquired Hawaii, a foothold in Samoa, Guam. And then, in the war for Cuban independence, we acquired the Philippines. It was no accident that our leading theorists were navy captains and admirals. Throughout the expanse of the Pacific and its satellite seas, the gunboat became the symbol of America, even as the Statue of Liberty had become the symbol for Europe.

This is, of course, an oversimplification, as any statement must be which attempts to summarize a vast complex of events occurring over nearly a century of time. But it is essentially true and sufficiently precise for the purposes of our present analysis. Certainly, following the conclusion of the War Between the States, we assumed a role in the Pacific not unlike that of the British in the Atlantic and became the guardians in that area of the world balance of power. Indeed, we entered into a kind of tacit partnership with England under which we helped to protect her position in Asia, while she protected ours in the Caribbean. It is significant, in this respect, that the "Open Door" policy in China, enunciated in John Hay's famous

\footnotetext{
'See generally J. W. Foster, American Diplomacx in the Orient (Ig03); Parker T. Moon, Imperialism and World Politics (igig); P. J. Treat, Japan and the United States (ig2i); S. F. Bemis, A Diplomatic History of the United States (1955).

${ }^{8} 2$ Samuel Eliot Morison and Henrx Steeze Commager, The Growth of the American RePUBLIC 6r2 (4th ed. 1950 ).

${ }^{9}$ Alfred T. Mahan, Interest of America in Sea Power, Present and Future 21 (1897).
} 
circular note of September 6, I899, was urged upon us, in the first instance, by the British Foreign Office. The Sino-Japanese war had revealed the weakness of China to all the world, and all the world rushed in to stake a claim. The resultant scramble not only threatened the interests of the United States and the privileged position of Great Britain in the Far East, but the entire world balance of power. The "Open Door" policy was an intervention designed to limit the extension of European imperialism in China and, by this means, to preserve that power balance.

From the outset, therefore, we played a power role in the Pacific, with our navy visibly to the fore. This fact has inevitably colored the Asian image of America. Whatever else a show of force may accomplish-and it may accomplish a great deal-it seldom endears one to those against whom it is directed; and the symbol of the Big Stick has never been an appealing one to the peoples of less developed areas. The point is but partially altered by the fact that our imperial aspirations were short-lived and that we were less brazenly imperialistic than others. We were identified with white colonialism and and with its overtones of racial superiority, even when (or perhaps, especially when) our objectives were benevolent. One may respect force, and its judicious exercise may even induce consent. But it is normally regarded with suspicion by those who do not possess it, even when it is employed in their behalf. One may learn regard for one's "betters," but the learning only buries more deeply the resentment which grows in men when they are treated as inferiors by virtue of status.

I have dwelt upon this at some length because it is crucial to an understanding of the problems we face in the great arc of Asia and the Middle East. Those problems have been magnified by our past immigration policies and are made more difficult by our present ones. Throughout, discrimination based on color or colonial status, has been undisguised-a fact which has not escaped the attention of any informed person in the areas involved and has led to a long series of diplomatic protests from their governments.

Our earliest policy towards oriental immigration was identical to that we applied in respect to European. Under the Burlingame Treaty of $1868,{ }^{10}$ Chinese were specifically given the right to immigrate to the United States. But within a decade, anti-Chinese feeling became so strong on the West Coast that the abrogation of the treaty was demanded in the Congress. A bill to this effect was actually passed in I879, but was vetoed by President Hayes. However, the feeling was so intense that the President appointed a committee to negotiate a new treaty. The result was the treaty regulating immigration from China of $x 880 .{ }^{11}$

This treaty marked the beginning of our traditional discriminatory policy. The first article provided:

\footnotetext{
${ }^{10}$ Treaty of Trade, Consuls, and Emigration, July 28, I868, I6 Stat. 739, I William M. Marlor, Treaties, Conventions 234 (igio).

${ }^{11}$ Treaty between the United States and China Concerning Immigration, Nov. 17, I880, 22 STaT. 826, I Mallox, op. cit. stipra note Io, at $237,238$.
} 
Whenever in the opinion of the Government of the United States, the coming of Chinese laborers to the United States, or their residence therein, affects or threatens to affect the interests of that country, or to endanger the good order of the said country or of any locality within the territory thereof, the Government of China agrees that the Government of the United States may regulate, limit or suspend such coming or residence, but may not absolutely prohibit at. . . .

That the prohibition against prohibiting was no more than a face-saver for the Government of China was shortly demonstrated. In 1882, President Arthur signed an act temporarily suspending Chinese immigration for a period of ten years and prohibiting the naturalization of Chinese. ${ }^{12}$ The law was subsequently extended until it became permanent. ${ }^{13}$ Except for a few students, the immigration of Chinese was, in fact, prohibited from I882 until December I7, I943, when President Roosevelt signed a repealer of the Exclusion Act. ${ }^{14}$ At that time, the Chinese were our allies in the struggle against Germany and Japan.

The exclusion policy evoked a series of diplomatic protests by the Government of China, led to riots in China, and to organized boycott of our trade. The boycott of rg04-06 was so extensive and well-organized that it virtually destroyed our China trade. But the long-time results in terms of attitudes, of racial and international antagonisms, were far more serious than the loss of commercial opportunities. By such short-sighted racist policies, we helped to prepare the ground for the successful tour of Khrushchev and Bulganin in Southeast Asia and to provide a receptive setting for the speeches of Chou En Lai at the Bandung Conference.

When, finally, the Chinese Exclusion Act was repealed and China placed on the same footing as the countries of Europe, the Chinese quota turned out to be 105. ${ }^{15}$

Our treatment of Japan was equally well-contrived to lose us friends. Prior to I90o, there was relatively little Japanese immigration into the United States, though larger numbers had emigrated to Hawaii. Nevertheless, the Japanese, too, were caught up in the hysteria of the "Yellow Peril." In Ig06, when the San Francisco School Board ordered segregated schools, Nisei were included with Chinese in the groups affected. The result was a wave of popular feeling in Japan which led to the famous Gentlemen's Agreement of $190 \%$, under which the Japanese Government itself undertook to refuse passports to Japanese workers wishing to come to the United States. ${ }^{16}$ Thus, for a time, "face"-that matter of infinitely vital importance in all eastern cultures-was saved for the Japanese.

But we could not leave it at that. The Immigration Act of $1924^{17}$ included a Japanese exclusion clause, even though less than $25^{\circ}$ would have been eligible to

12 Act of May 2, 1882, c. 126, 22 STAT. 58.

${ }^{13}$ Act of April 27, 1904, c. $1630, \S 5,33$ STAT. 428. For a brief summary of Chinese exclusion legislation, see 6 Docs. AM. For. ReL. I943-44, at 607-09, 612-16 (x945).

${ }^{14}$ Act of Dec. 17, r943, c. 343,57 Stat. 600.

${ }^{16}$ Proclamation No. 2603, Feb. 8, 1944 (Immigration Quota for Chinese) 58 STat. r125 (1944).

${ }^{10}$ See U. S. Comm'r of Immigration, Report 125 (1908). For the full text, see 2 U. S. Dep't op State, Papers Relating to the Foretgn Relations of the United States, 1924, at 337-7x (1939).

${ }^{17}$ Act of May 26, 1924, c. 190, 43 Stat. 153. 
come in under the established quota system. The result was to destroy by a single act all the warm feelings created by our humanitarian help following the earthquake of I $_{23} 3$ and to plant the seeds of bitterness which were not long in bearing fruit.

Certainly, it must be clear that while the objectives of foreign policy are the furtherance of the interests of the nation concerned, the available means to achieve them are essentially psychological, economic, and military. I put them purposely in this order because I believe that the tests of history rank them in this order in terms of effectiveness. If this is true-or even approximately so-the image we reflect is at least as important in attaining our foreign policy objectives as the size of our guns or the extent of our atomic stockpile. Yet, the image we have ourselves built up in Asia, partly as a result of imperialistic ventures and of our support of colonialism, and partly as a result of our immigration policies, has produced a psychological setting in which our propaganda efforts are largely nullified. To the extent-and it is a very large extent-that the present struggle is one for the minds of men, we thus start under a handicap produced by prejudiced policies on immigration.

This would have been less serious in its ultimate results had we, or the other western powers, wished to promote industrialization in Asia and thus to reduce the pressure of population. But neither we, nor anyone else, until very recent times, desired to take such a step. Economic aid and technical assistance, combined with defensible policies on immigration, may yet win the day. But it is very late, and we still have not understood the seriousness of the negative impact of our immigration laws.

Even after World War II, when we had become the leading power in the world and were deeply involved in every part of it, new immigration legislation reflected in its restrictionist policies an isolationism realistically dead for a generation. Even more serious, from the standpoint of our foreign objectives, it again projected the old racial prejudices and those against peoples still in a colonial status. The Immigration and Nationality Act of 1952 , popularly known as the McCarran-Walter Act, ${ }^{18}$ retained the quota principle and the national-origins formula of the I924 Act. It was almost as though nothing had happened in the world during a revolutionary period when it was actually set on end. Almost, but not quite. The I952 Act did repeal the Japanese exclusion provision, allot to Japan a minimum quota, and make Japanese eligible for naturalization. This was, without any doubt, a major step in the right direction. ${ }^{19}$

But it carried forward other irritating and questionable policies and added one or two new ones equally well designed to make life difficult in the State Department. In the Act of I9I7, Congress had flagrantly displayed the racist basis of its thinking

${ }^{18} 66$ STAT. I63, 8 U. S. C. \$\$ Iror-503 (1952).

${ }^{10}$ Much has been made by proponents of this act of its liberalizing features in respect to Asia. On this score, it is interesting to note that an annual total of 1,423 quota immigrants were permitted under the 1924 Act ( 1929 formula) as compared with a total of 2,990 under the McCarran-Walter Act. 
by establishing the so-called Asiatic barred zone. ${ }^{20}$ The relevant provisions flatly declared that natives of a large area of Asia and the Pacific were ipso facto inadmissible as immigrants, without regard to any other considerations. The barred zone included parts of China and all of India, Siam, Burma, the Malay Archipelago, the - East Indies, and the Polynesian Islands. The prohibition was continued in the Act of 1924. While the McCarran-Walter Act liberalized some of the restrictionist features of the earlier legislation in respect to Asia, it retained the idea of the barred zone in the guise of the "Asia-Pacific triangle."21 This vast area, somewhat larger than the barred zone, has been assigned a total annual quota of roo visas, in addition to minute separate quotas for countries within the area. But at the same time, the law provides that any prospective immigrant, regardless of his place of birth, who is "attributable by as much as one-half of his ancestry to a people or peoples indigenous to the Asia-Pacific triangle" is chargeable either against the quota of the triangle or against that of the country of his Asian ancestor. Thus, a British national, born in London of a British father and a Burmese mother would be charged, not against the ample British quota, but either against that of Burma or the roo visas of the Asia-Pacific triangle.

This is hard to defend on any ground. The numbers involved in a nondiscriminatory approach would be so small as to be insignificant. Yet, the propaganda value of such discriminatory provisions to those nations or groups hostile to the United States is obviously enormous. It is, moreover, being fully exploited by the Russians in their "New Look" policy.

The 1952 Act also underscored racism and a bias against colonial peoples by its provisions in respect to the western hemisphere. Even under the I924 Act, a native of a colonial dependency in this hemisphere could enter under the quota of his mother country. Under the McCarran-Walter Act, this is changed. Separate quotas of roo have been allotted to such dependencies, and the British quota, for example, is no longer available to Jamaicans. ${ }^{22}$

All of this might be a matter only for our own consciences were it not for the palpable fact that provisions like the ancestry test for Orientals and the barriers against the colonial peoples of the western hemisphere play squarely into the hands of our adversaries in the great struggle now going on to establish a new balance of power in the world. Through our immigration policies, we have managed to rub salt into the deepest wounds of two-thirds of the people of the world. Moreover, as we do not tire of pointing out to the Russians, deeds speak louder than words. It is difficult for the Voice of America to explain away what we are doing in these fields. At the moment, when we are calling for a united free world opposed to Communism, our immigration policies are based on invidious distinctions among countries and nationalities, including the very countries we wish to ally with us.

${ }^{20}$ Act of Feb. 5, 1917, c. 29, $\$ 3,39$ STat. 875 .

${ }^{21} 66$ STAT. I77, 8 U. S. C. $\S$ Ir52(b) (1952).

${ }^{22} 66$ STAT. I77, 8 U. S. C. \$1152(c) (1952). 
III

In a famous observation, applicable to post-war Europe, Sir Wilmott Lewis remarked that "we have chaos, but not enough to make a world." What he most certainly had in mind was the dissolution of the balance of power in Europe as a result of the war, and in Asia and the Middle East as a consequence of the collapse of the colonial system. In both instances, a considerable volume of chaos followed; but enough residue remained of the old system to make an entirely fresh start both inadvisable and impossible.

Thus, Humpty-Dumpty having tumbled from the wall with a crash, has now to be put together again with different materials and a radically altered shape. In the process, we are understandably undertaking to keep as much as we can and to fashion new pieces and new combinations of pieces to replace those shattered beyond recall. This is an arduous, a delicate, and a dangerous undertaking. But it is an unavoidable one, and is, in summary, what we are about.

We are, consequently, squarely in the midst of that agonizing reappraisal of our world role and our foreign policy objectives which Secretary Dulles periodically implies is still around the corner. We have, in fact, been engaged in it ever since we belatedly discovered that we could not safely leave a power vacuum where the Axis powers formerly stood and since we first began to understand the threat posed to our whole way of life by Russian imperialism when combined with the Communist religion.

As is our custom, we have adjusted to our altered position in the world by fits and starts and have proceeded by zig-zags rather than along straight lines. Our tactics, even though confused and uncertain, have been generally better than our strategic conceptions, as befits a pragmatic people suspicious of general principles. Perhaps our most serious aberration has been to confuse our principal objective of restoring a stable balance of power (without which there can be neither security nor peace in the world) with the messianic and visionary objective of eliminating Communism, or even socialism, from the world. This has made difficult the determination of priorities among immediate objectives and has frequently plagued us in our choice of means. It has resulted in a substitution of ideological slogans for programs and in a whole series of verbal "brinks," "unleashings," and "liberations" which had little relation to reality or to policy objectives. It is doubtful if any of this bewildered our antagonists, but it did serve to confuse our own people and to confound our allies. There have even been times when it has seemed to confuse our leaders.

But with it all, we have not done too badly, if we consider how far we have had to come. We have been groping our way in a new world with few familiar landmarks and adjusting ourselves to an unaccustomed status in that world. Under the circumstances, it is hardly surprising that so many obsolescent ideas and preconceptions still enter our thinking. Humpty-Dumpty was pretty well smashed up, and 
it will be some time before the new pieces are fashioned and he is wholly restored to his wall.

To a remarkable degree, the difficult but exciting world in which we find ourselves today is of our own making. The major forces which have shaped it can be readily traced to the ideas of the American and French Revolutions, the Emancipation Proclamation, and the Wilsonian notion of the self-determination of nationalities. These ideas, in one form or another, acting and reacting, have combined to shatter the power structure of the world and to usher in a period of revolutionary instability. The old power system was based essentially on an intricate balance of forces among all the great colonial powers. Whatever its faults-and they were manifold and manifest-it preserved the peace until upset by the challenge of Germany in the West and Japan in the East and by the subsequent disintegration of the whole colonial system.

Twice, we ventured out of our accustomed seclusion to attempt to restore the balance as we had known it. Twice, we destroyed the physical force of the aggressors. But we could not, by military means, restore the moral force of the old order nor check the sweep of revolutionary ideas. As Dean Acheson has rightly said: "Force can only overcome other force. When it has done this, it has spent itself and other means of influencing conduct have to be employed." ${ }^{23}$ In I9I8, we naïvely hoped the balance of power had been restored by the single act of our military intervention, and we withdrew into our borders to enjoy the results. In 1945, confronting the Red Army in Berlin, the rubble of a devastated Europe all about us, we started down the long road to understanding that a secure balance of power could be achieved only through our sustained leadership and efforts. ${ }^{24}$ The measure of our understanding has been the Truman Doctrine, the Marshall Plan, NATO, Point Four, and collective interdiction in Korea. These are all facets of a single effort. They are aimed, not at the destruction of Soviet power, but at its containment, with a view to achieving a new balance of power which may secure peace in the world.

There have, of course, been vocal minorities who have not agreed with this objective and who have failed to realize that checks and balances are as important to international peace and security as they are to domestic freedom. There have been those who would make the world-wide destruction of Communist power the prime objective, whatever its costs in life or in our democratic way of life. But these have been minority views, capable of causing shifts in tactics but not in goals. The goal has remained an equilibrium of power. "The international relations of our modern world," Louis Halle observes, "as they tend to fall into a balance of power, tend to be relations either of association or of opposition."25 What we, therefore, have been attempting to do is to associate as many peoples with us as

${ }^{23}$ Dean Acheson, a Democrat looks at His Party 76 (1955).

${ }^{24}$ For a brilliant exposition of this point and of the alternatives beforc us in forcign policy, sce Lours J. Halle, Civilization and Foreign Policy (1955).

${ }^{25} I d$. at 92 . 
possible. While Russian methods have obviously differed from ours, their goal has been identical. The result of these opposed efforts has been the Cold War.

Our own efforts have been conspicuously successful in Europe, where no outright Soviet successes have been scored since the coup in Czechoslovakia, and where we have largely succeeded in fashioning a coalition. Our allies there may shudder at our impetuosity and chafe at the notion that they should constantly show gratitude for measures we have undertaken in our own self-interest, but these are surface irritations. Our differences are within the family and are viable.

The situation in Asia and Africa is altogether different. In these areas-with a few notable and understandable exceptions-we have been able to secure no more than an uneasy neutralism. I shall not argue here whether a neutral "third force" might not ultimately become a stabilizing factor in the world power balance. The point is that in these areas, as in Europe, our aim has been association rather than neutralization. In this, we have so far failed. The reasons for this failure are directly related to the theme of this paper.

It is undeniably difficult for a people who have generally been as well-intentioned as we have been and whose adventures in colonialism were so casually brief to realize the depth of the revolution which is sweeping Asia and Africa or the ideological and emotional elements composing it. The fuel which feeds the revolution is a subtle and highly volatile combination of nationalism, racial sensitivity, and economic aspiration. Its ideology is egalitarian, pacifist, and socialistic, and its emotional drive is supplied by the deep resentments and racial antagonisms produced in a century and a half of white supremacy and of white exploitation. It is prideful and overly concerned with the restoration and preservation of face. As Nehru himself has commented, "Psychology counts and racial memories are long."20

Against this background, SEATO Pacts, military assistance and maneuvers, defensive alliances, have little appeal. Indeed, they may react adversely, for they once more evoke the ancient image of the gunboat and of naked power. Nor do prideful people appreciate even technical assistance with obvious strings attached. These are real difficulties, but they do not constitute the nub of the problem.

What we are really up against in the whole vast, uncommitted area is a suspicion of our intentions, our methods, and our ideals. This was clearly evident in the proceedings at Bandung, where consideration of four key issues dominated the conference: colonialism, racism, economic development, and peace. ${ }^{2 \pi}$ In the eyes of much of Asia and Africa, we are suspect on each of these, not because of our current foreign policy, but because either of what we have done in the past or of what we are still doing in our own domestic affairs.

The day has passed when a clear line can be drawn between domestic and foreign policies. What a nation does speaks louder than what it professes, and

\footnotetext{
20 Chester Bowles, Ambassador's Report 54 (1954). (1955).

${ }^{27}$ For an illuminating analysis, see Chester Bowles, The New Dimensions of Peace 2 I8 et seq.
} 
modern means of communication make certain that what we do, even in internal matters, will quickly be known throughout the world. To more than a billion uncommitted people, our practices in terms of racial equality and respect for individual dignity have far greater meaning than all the broadcasts of the Voice of America combined. Discriminatory provisions in our immigration laws, based on archaic and demonstrably false assumptions of racial or national superiority and of the inferiority of colonial peoples, subvert our efforts to form a free coalition, play squarely into the hands of Communist propagandists, and constitute a disruptive factor in the search for peace. These are luxuries we can ill afford in the present-day world. 